Author-produced version of the article published in Waste Management

Original publication available at www.elsevier.com - doi:10.1016/j.wasman.2009.10.018

\title{
COMPARISON OF FIVE ORGANIC WASTES REGARDING THEIR BEHAVIOUR DURING COMPOSTING: PART 2, NITROGEN DYNAMIC
}

\author{
A. de Guardia *, P. Mallard, C. Teglia, A. Marin, C. Le Pape, M. Launay, J.C. Benoist, C. Petiot
}

1- Cemagref, UR GERE, 17 Avenue de Cucillé, CS 64427, F-35044 Rennes, France.

2- Université européenne de Bretagne, F-35000 Rennes, France.

7

* Corresponding author. Tel. : +33223482133; Fax : +33223482115.

E-mail address: amaury.de-guardia@ cemagref.fr. 
1

\section{Abstract}

This paper aimed to compare household waste, separated pig solids, food waste, pig slaughterhouse sludge and green algae regarding processes ruling nitrogen dynamic during composting. For each waste, three composting simulations were performed in parallel in three similar reactors $(300 \mathrm{~L})$, each one under a constant aeration rate. The aeration flows applied were comprised between 100 and $1100 \mathrm{~L} / \mathrm{h}$. The initial waste and the compost were characterized through the measurements of their contents in dry matter, total carbon, Kjeldahl and total ammoniacal nitrogen, nitrite and nitrate. Kjeldahl and total ammoniacal nitrogen and nitrite and nitrate were measured in leachates and in condensates too. Ammonia and nitrous oxide emissions were monitored in continue. The cumulated emissions in ammonia and in nitrous oxide were given for each waste and at each aeration rate. The paper focused on process of ammonification and on transformations and transfer of total ammoniacal nitrogen. The parameters of nitrous oxide emissions were not investigated. The removal rate of total Kjeldahl nitrogen was shown being closely tied to the ammonification rate. Ammonification was modelled thanks to the calculation of the ratio of biodegradable carbon to organic nitrogen content of the biodegradable fraction. The wastes were shown to differ significantly regarding their ammonification ability. Nitrogen balances were calculated by subtracting nitrogen losses from nitrogen removed from material. Defaults in nitrogen balances were assumed to correspond to conversion of nitrate even nitrite into molecular nitrogen and then to the previous conversion by nitrification of total ammoniacal nitrogen. The pool of total ammoniacal nitrogen, i.e. total ammoniacal nitrogen initially contained in waste plus total ammoniacal nitrogen released by ammonification, was calculated for each experiment. Then, this pool was used as the referring amount in the calculation of the rates of accumulation, stripping and nitrification of total ammoniacal nitrogen. Separated pig solids were characterised by a high ability to accumulate total ammoniacal nitrogen. Whatever the waste, the striping rate depended mostly on the aeration rate and on the pool concentration in biofilm. The nitrification rate was observed as all the higher as the concentration in total ammoniacal nitrogen in the initial waste was low. Thus, household waste and green algae exhibited the highest nitrification rates. This result could mean that in case of low concentrations in total ammoniacal nitrogen, a nitrifying biomass was already developed and that this biomass consumed it. In contrast, in case of high concentrations, this could traduce some difficulties for nitrifying microorganisms to develop.

Keywords: Organic waste, composting, nitrogen dynamic, ammonification, nitrification, ammonia emissions, nitrous oxide emissions. 


\section{Introduction}

Concern with nitrogen dynamic in composting aims to identify the ways allowing to reduce ammonia and nitrous oxide emissions either by keeping nitrogen in compost or through its conversion into molecular nitrogen. Indeed, nitrous oxide is a powerful greenhouse gas and ammonia emissions contribute to bad odours around composting plants and take part to the eutrophication of ecosystems and to acid rains. More, losses in nitrogen reduce the fertilizer value of the compost.

In their review on environmental impacts of biological treatments of organic waste, Mallard et al. (2006) estimated ammonia emissions during composting around $0.2 \mathrm{~kg} \mathrm{~N}-\mathrm{NH}_{3} / \mathrm{Mg} \mathrm{DM}$ for green waste and around 4.5 for wastewater sludge, between 0.6 and 1.2 for household waste, between 1.4 and 9.4 for pig and cattle manure and between 4 and 6 for biowaste. Komilis and Ham (2006) found that these emissions were 2, 4.4 and $34 \mathrm{~kg} \mathrm{N-}$ $\mathrm{NH}_{3} / \mathrm{Mg} \mathrm{DM}$ for respectively paper, green waste and food waste whereas Pagans et al. (2006) found that these emissions were $0.47,0.17$ and $7.67 \mathrm{~kg} \mathrm{~N}-\mathrm{NH}_{3} / \mathrm{Mg} \mathrm{OM}$ for respectively organic fraction of municipal solid waste, raw sludge and animal by-products. Emissions of nitrous oxide, expressed as equivalent $\mathrm{CO}_{2}$ regarding green house effect, range between 2 and $50 \mathrm{~kg} \mathrm{CO} / \mathrm{Mg} \mathrm{DM}$ for biowaste, between 5 and 125 for household waste, between 10 and 1700 for pig and cattle manure and around 340 for wastewater sludge (Mallard et al., 2006).

These results indicated that there is a wide variation of ammonia and nitrous oxide emission resulting from different waste nature and composting conditions.

Assuming microorganisms use 15-30 parts of carbon for each part of nitrogen, low $\mathrm{C} / \mathrm{N}$ ratios were often considered being responsible for higher emissions of ammonia (Okereke and Meints, 1985, Pagans et al., 2006, Tiquia and Tam, 2000, Zhu, 2007), whereas high C/N ratios would allow to immobilize and even fix nitrogen (Liang et al., 2006). However, as reported by Kirchmann and Witter (1989), many authors did not observe any reduction of ammonia emissions as $\mathrm{C} / \mathrm{N}$ was increased. Then, some claimed for the account of the biodegradabilities of carbon and nitrogen instead of its chemical concentrations (Liang et al., 2006; Paillat et al., 2005; Paré et al., 1998). Indeed, Liang et al. (2006) observed that the addition of sucrose reduced nitrogen losses during composting of manure with straw whereas the addition of paper had low influence on ammonia volatilization. Liang et al. (2006) also reported that Subair (1995) and Witter (1986) found that low amounts of glucose were effective in reducing emissions of $\mathrm{NH}_{3}$ when composting liquid hog manure and sewage sludge with straw. 

of ammonia. Thus ammonia emissions were found all the higher as the aeration rates (de Guardia et al., 2008; Körner and Stegmann, 2003; Liang et al., 2004), the temperatures (Pagans et al., 2006; Witter and Lopez-Real, 1987) and the pH (Beck-Friis et al., 2001; Cronje et al., 2002; Ekinci et al., 2000; Pagans et al., 2006) were high. denitrification too. The concentrations of nitrite and nitrate measured in composting materials were usually low (Lemus and Lau, 2002), which could result whether to low nitrification rates or most probably to denitrification following nitrification. In addition, since molecular nitrogen produced through denitrification is low compared to $\mathrm{N}_{2}$ concentration in air, denitrification can not be easily quantified by measurement of $\mathrm{N}_{2}$ in exhaust gazes. Then, nitrification and denitrification were usually considered on basis of a qualitative approach when the nitrogen balance was not coherent. The oxygen concentration, the concentration in $\mathrm{NH}_{4}^{+} / \mathrm{NH}_{3}$ and the temperature in composting material were invoked to account for nitrification and denitrification rates (Bishop and Godfrey, 1983; Eiland et al., 2001; Körner et al., 1999; Körner and Stegmann, 2003; Tiquia and Tam, 2000; Wong et al., 2001). The increase of nitrate, when most of the biodegradable matter was biodegraded and when the concentration in total ammoniacal nitrogen and the temperature decreased, was interpreted as being due to both the availability of oxygen and the achievement of optimal temperatures for nitrification. In contrast, others considered denitrification occurred even when oxygen concentration was higher than $15 \%$ and they attributed the increase of nitrate to a slow-down of denitrification resulting from a diminishing of biodegradable organic matter (Lemus and Lau, 2002; Liang et al., 2006).

In agreement with theory, ammonification leads to the release of total ammoniacal nitrogen, which then adds to total ammoniacal nitrogen initially present in the waste. Then, this pool of total ammoniacal nitrogen is either immobilized as organic nitrogen, accumulates in compost, is emitted as ammonia or is converted into nitrate then molecular nitrogen through nitrification and denitrification. Thus, the removal of nitrogen from material results mostly from the transformations and the transfer of total ammoniacal nitrogen. However, few papers (de Guardia et al., 2008) took into account the amount of organic nitrogen ammonified in the calculation of the rates of accumulation, stripping and nitrification.

More, although Martins and Dewes (1992) underlined the influence of ammonification on ammonia emissions and although the peak of ammonia emissions occurred when biological activity was maximum (Körner et al., 1997), i.e. at the peak of material temperature (Bhoyar et al., 1979), the correlation between 
assumption that ammonification was closely tied to carbon biodegradation and to organic nitrogen content of the biodegradable fraction, de Guardia et al. (2008) and Liang et al. (2006) assumed a correlation between organic nitrogen ammonified, $\Delta$ Norg, and organic carbon removed, $\Delta$ Corg:

$$
\Delta \text { Norg } \approx \Delta \operatorname{Corg} \times[1 /(\text { TC } / \text { Norg })]
$$

with TC/Norg, the ratio of carbon to organic nitrogen of either the biodegraded fraction (Liang et al., 2006) or of the initial substrates (de Guardia et al., 2008).

This state of the art showed that there was still a need for a better understanding of processes ruling nitrogen dynamic during composting. This study aimed to compare five organic waste, i.e. household waste, separated pig solids, food waste, pig slaughterhouse sludge and green algae, regarding their behaviour towards organic nitrogen mineralization, ammonia striping, $\mathrm{NH}_{4}{ }^{+} / \mathrm{NH}_{3}$ accumulation in compost, nitrification and denitrification. Composting conditions like aeration and temperature were also investigated as potential parameters of ammonification, accumulation, striping and nitrification. Composting experiments were performed in lab-pilots under forced aeration.

\begin{tabular}{|c|c|c|c|}
\hline \multicolumn{4}{|c|}{ Nomenclature } \\
\hline $\mathrm{C}_{\text {bio }}$ & biodegradable carbon & N-nit & nitrogen nitrified \\
\hline \multicolumn{2}{|c|}{ Cbio/Nbio $\mathrm{C} / \mathrm{N}$ ratio of the biodegradable fraction } & NK & Kjedahl nitrogen \\
\hline COD & chemical oxygen demand & Norg & organic nitrogen \\
\hline $\mathrm{CV}$ & coefficient of variation & $\mathrm{NO}_{2}^{-}$ & nitrite \\
\hline $\mathrm{C} / \mathrm{N}$ & carbon to nitrogen ratio & $\mathrm{NO}_{3}^{-}$ & nitrate \\
\hline DM & dry matter & $\mathrm{OM}$ & organic matter content \\
\hline FW & food waste & $\mathrm{OM}_{0}$ & initial content in organic matter \\
\hline GA & green algae & $\begin{array}{l}P \\
\text { initial }\end{array}$ & $\begin{array}{l}\text { pool of } \mathrm{NH}_{4}^{+} / \mathrm{NH}_{3} \text { contained in } \\
\text { ste and released by ammonification }\end{array}$ \\
\hline HW & household waste & PSS & pig slaughterhouse sludge \\
\hline $\mathrm{NH}_{4}{ }^{-}$ & 3 total ammoniacal nitrogen & SPS & separated pig solids \\
\hline $\mathrm{NH}_{3}$ & ammonia & $\mathrm{TC}$ & total carbon \\
\hline $\mathrm{N}_{2} \mathrm{O}$ & nitrous oxide & WC & wood chips \\
\hline
\end{tabular}

\section{Methods}

\subsection{Materials used and performance of experiment}

The waste were collected on site less than $24 \mathrm{~h}$ before each composting simulation. The household waste (HW) was collected at a composting plant (Launay-Lantic, Brittany, France). After three days in a rotating drum, the household waste were submitted to mechanical sorting to extract impurities. Finally, they were mixed 
with yard waste to achieve their composting. Here, HW was sampled after mechanical sorting and before composting. The food waste (FW) was collected at a cafeteria. The separated pig solids (SPS) were sampled at a pig livestock. They corresponded to the solid fraction obtained following centrifugation of pig slurry. The pig slaughterhouse sludge (PSS) was collected at the wastewater treatment plant of a slaughterhouse. The green algae (GA) were collected on the beach of St Michel en Grèves in Brittany. They were rinsed then, drained for $24 \mathrm{~h}$ before the composting experiments. The household waste, the food waste, the pig slaughterhouse sludge and the green algae were mixed with calibrated wood chips (WC), which dimensions ranged between 12.5 and $30 \mathrm{~mm}$. Moisture content of the mixtures was comprised between 56 and 70\%. In the case of PSS, the sludge was sampled between January and October of the same year. Except for PSS, the same waste was loaded in three similar reactors. These consisted in insulated cylindrical chambers $(300 \mathrm{~L})$ in which air was blown at the bottom then crossed the material. A constant aeration rate was applied on each reactor meaning the behaviour of each waste was studied as it was submitted to three different aeration rates. The aeration rates were comprised between 100 and $1100 \mathrm{~L} / \mathrm{h}$. The value of the highest aeration flow was chosen on basis of airflows applied at real scale. The medium and the lowest ones were selected in order to, whether limit biodegradation thanks to oxygen supply (PSS at $105 \mathrm{~L} / \mathrm{h}$ ), or achieve complete stabilisation i.e. avoid limitation by drying too fast the material. The in-coming airflow, the material temperature and its total mass were measured in continue thanks to respectively a volumetric gas meter, three Pt100 probes and weigh sensors. The exhaust gases were collected at the top of the reactors and the condensates formed were trapped in bottle condensers. The condensates and the leachates were weighed every day then, analysed. Concentrations of oxygen, carbon dioxide, methane, ammonia and nitrous oxide were measured in both the in-coming and out-going airflows. The emissions of ammonia were measured for each waste and at each aeration rate whereas nitrous oxide emissions were measured for only household waste, food waste and green algae. The material was turned once, twice or three times during composting. The composting was stopped when the oxygen consumption rate seemed constant and around zero. The experiments lasted from 27 to 50 days. The details relating to initial and final characteristics of the mixtures and to experimental conditions were given in Table 1 in Part 1 of this pair of articles.

\subsection{Pre-treatments and chemical characterization of the waste and of the mixtures}

As much as possible, in order to reduce losses through drying, the chemical characterization was applied on moistened waste i.e. without any drying. Thus, taking into account its low particle dimensions, separated pig solids and composted ones were characterized without any drying neither grinding. The characterization of the composted mixtures containing wood chips made other risks i.e. under or over-estimate one of its components. 
Thus, for mixtures of green algae with wood chips, the strategy consisted to separate the composted waste from the wood chips by mechanical sieving and even manual separation. For mixtures of household waste with wood chips and pig slaughterhouse sludge with wood chips, mechanical screening was coupled with aqueous extractions. For food waste, the initial waste and the mixture obtained after composting were dried then ground before characterization. Taking into account wood chips pieces dimensions and that they biodegraded slower than studied waste, the method assumed that the wood chips were inert meaning wood chips obtained after composting were not characterized. Whatever the pre-treatment, the same was applied on initial and composted waste.

Thus, as mentioned earlier, separated pig solids and composted ones were characterized without any drying neither grinding. Fresh and composted green algae were cut in a food grinder without any drying, and then, they were characterized. Taking into account that the composted household waste and composted pig slaughterhouse sludge remained adsorbed on the wood chips, the separation was achieved thanks to mechanical sieving coupled with aqueous extractions. Such extraction also reduced losses through drying since volatile compounds adsorbed on solids, i.e. composted waste or wood chips, were trapped in the aqueous extracts. Then, the aqueous extract was characterized with the standard methods used for liquids. The solids were dried then analysed. The global composition was obtained by adding each phase contribution. Taking into account sanitary risks, i.e. pathogens and odours, initial food waste and composted mixtures, i.e. food waste plus wood chips, were not submitted to aqueous extractions. The high dimensions of food waste particles led to dry then grind initial waste and composted mixtures before their chemical characterization. In this case, the wood chips were assumed inert regarding the duration of the experiments and their contribution was subtracted from the characterization applied on the final global mixture i.e. composted food waste plus wood chips

The initial and composted wastes were characterized for their content in dry matter (DM), organic matter (OM), total carbon (TC), chemical oxygen demand (COD), Kjeldahl nitrogen (NK), total ammoniacal nitrogen $\left(\mathrm{NH}_{4}{ }^{+} / \mathrm{NH}_{3}\right)$, nitrite $\left(\mathrm{NO}_{2}{ }^{-}\right)$and nitrate $\left(\mathrm{NO}_{3}{ }^{-}\right)$. Whatever the waste, the compost or the composted mixture, three samples at the minimum were pre-treated then analysed. If the coefficient of variation (CV) was inferior to 5\%, then the analysis was registered. If not, some additional samples were submitted to pre-treatment and analysis. In the case of analysis practised on moistened material, the heterogeneity was higher than for dried and ground materials, which led to characterize 5 to 15 samples to get $\mathrm{CV}$ inferior to $5 \%$.

The contents in $\mathrm{TC}, \mathrm{COD}, \mathrm{NK}, \mathrm{NH}_{4}{ }^{+} / \mathrm{NH}_{3}, \mathrm{NO}_{2}{ }^{-}$and $\mathrm{NO}_{3}{ }^{-}$, of the condensates and of the leachates, were measured too. Each sample collected was analyzed three times leading to CV inferior to 5\%. 

in Part 1.

\subsection{Methods for calculation of the rates of ammonification, accumulation, stripping and nitrification}

Organic nitrogen content was obtained by subtracting total ammoniacal nitrogen from Kjeldahl nitrogen. Then, thanks to the knowledge of the mass of waste loaded in the reactor and of the mass of the composted waste and thanks to characterizations applied on initial and composted waste, it was possible to calculate the mass of organic nitrogen in the initial waste and in the composted one. The rate of ammonification was obtained by dividing the mass of organic nitrogen removed during composting by the mass of organic nitrogen contained in initial waste.

Ammonification leading to the release of total ammoniacal nitrogen and the removal of nitrogen from material being due at first to the transformations and to the transfer of total ammoniacal nitrogen (Figure 1), both were considered in the calculation of the rates of accumulation, striping and nitrification of total ammoniacal nitrogen. Then, the pool $\mathrm{P}$ was defined as the addition of the mass of total ammoniacal nitrogen contained in initial waste plus the mass of total ammoniacal nitrogen released by ammonification:

$$
P=N_{-} \mathrm{NH}_{4}^{+} / \mathrm{NH}_{30}+\Delta \mathrm{Norg}
$$

The mass of total ammoniacal nitrogen released following ammonification, $\Delta$ Norg, corresponded to the mass of organic nitrogen removed during composting and mentioned above.

Thus, the accumulation rate was the ratio of the mass of total ammoniacal nitrogen contained in composted waste to the mass of pool P i.e. the mass of total ammoniacal nitrogen contained in initial waste plus the mass of total ammoniacal nitrogen released by ammonification, both potentially participating to accumulation.

The striping rate was the ratio of the mass of nitrogen emitted as ammonia to the mass of total ammoniacal nitrogen, which could potentially be emitted i.e. the mass of the pool P. Considering that nitrogen in condensates was mostly as $\mathrm{NH}_{4}{ }^{+} / \mathrm{NH}_{3}$ and that it came from condensation of the out-going gas, it was added to nitrogen emitted as ammonia.

In agreement with Figure 1, total ammoniacal nitrogen transformed by nitrification can be calculated by subtracting from the pool $\mathrm{P}$ the masses of total ammoniacal nitrogen accumulated plus the mass of total ammoniacal nitrogen striped as ammonia plus total ammoniacal nitrogen collected in condensates and in leachates. Then, as for the calculation of the rates of accumulation and striping, the rate of nitrification was 
calculated by dividing the mass of total ammoniacal nitrogen nitrified by the mass of $\mathrm{P}$ i.e. the mass of total ammoniacal nitrogen which could be potentially transformed by nitrification.

Figure 1 here

\section{Results and discussion}

\subsection{Chemical characteristics of the initial and composted waste}

The chemical characteristics of household waste, separated pig solids, food waste, pig slaughterhouse sludge, green algae and wood chips were given in Table 2 in Part 1. Considering all the studied waste, the mean value of TC was $572.1 \mathrm{~g} / \mathrm{kg}$ OM with a coefficient of variation $(\mathrm{CV})$ equal to $9 \%$ and the mean of COD concentrations was $1570 \mathrm{~g} \mathrm{O}_{2} / \mathrm{kg} \mathrm{OM}$ with a $\mathrm{CV}$ equal to $18.0 \%$. In contrast, the waste differed significantly to each other regards to their contents in organic matter and in Kjeldahl and total ammoniacal nitrogen. Thus, OM content was the lowest for green algae, 53.3\% DM, and the highest for food waste, 91.4\% DM. The N-NK concentrations ranged between 17 and $60 \mathrm{~g} \mathrm{~N}-\mathrm{NK} / \mathrm{kg}$ DM corresponding respectively to household waste and pig slaughterhouse sludge. The highest concentrations in $\mathrm{N}-\mathrm{NH}_{4}{ }^{+} / \mathrm{NH}_{3}$ were observed for separated pig solids and pig slaughterhouse sludge whereas $\mathrm{NH}_{4}{ }^{+} / \mathrm{NH}_{3}$ was under detection level $(0.01 \mathrm{~g} / \mathrm{kg} \mathrm{DM})$ in household waste. Since drying was responsible for high losses in total ammoniacal nitrogen, and taking into account that not any aqueous extraction was practiced for food waste, $\mathrm{N}-\mathrm{NH}_{4}{ }^{+} / \mathrm{NH}_{3}$ was not measured within. The chemical characterization showed that the wood chips differed from the waste mainly regards to their contents in nitrogen, which were inferior to $1.0 \mathrm{~g} \mathrm{~N}-\mathrm{NK} / \mathrm{kg} \mathrm{DM}$ and under detection level for $\mathrm{NH}_{4}{ }^{+} / \mathrm{NH}_{3}$. No nitrate neither nitrite were detected in the initial substrates.

The chemical characteristics of composted waste were given in Table 3 in Part 1. During composting, the concentrations in $\mathrm{N}-\mathrm{NK}$ and $\mathrm{N}-\mathrm{NH}_{4}{ }^{+} / \mathrm{NH}_{3}$ increased or decreased depending on the waste and on the aeration rate. No nitrate neither nitrite were detected in the composted waste.

\subsection{Ammonia and nitrous oxide emissions}

The cumulated emissions of ammonia and nitrous oxide measured on green algae were given Figures $2 \mathrm{a}$ and 2b as an illustration of $\mathrm{NH}_{3}$ and $\mathrm{N}_{2} \mathrm{O}$ emission profiles. As it was often mentioned in literature, the peaks of $\mathrm{NH}_{3}$ and $\mathrm{N}_{2} \mathrm{O}$ occurred either at the peaks of oxygen consumption rate or after material turning.

The highest levels of ammonia emissions were observed for pig slaughterhouse sludge, between 4.8 and 36.1 $\mathrm{g} \mathrm{N}-\mathrm{NH}_{3} / \mathrm{kg} \mathrm{OM}_{0}$ (Table 1). They ranged between 2.9 and $10.8 \mathrm{~g} \mathrm{~N}-\mathrm{NH}_{3} / \mathrm{kg} \mathrm{OM}_{0}$ for the food waste and the 
green algae (Table 1). The ammonia emissions were the lowest for the separated pig solids and the household

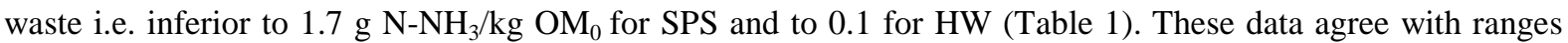
reported by Mallard et al. (2006). For a given waste, except for pig slaughterhouse sludge, the losses of nitrogen as ammonia emissions were all the higher as the aeration rate applied was high, which was in agreement with literature (de Guardia et al., 2008; Körner and Stegmann, 2003; Liang et al., 2004). However, this increase with aeration rate depended on the waste too. Indeed, this increase was significant for food waste, pig slaughterhouse sludge and green algae and almost negligible for household waste (Table 1). More, for pig slaughterhouse sludge, although nitrogen emitted as ammonia, i.e. in gas plus condensates, accounted for more than $80 \%$ of nitrogen removed from material at the two highest aeration rates, there was a decrease of ammonia emissions

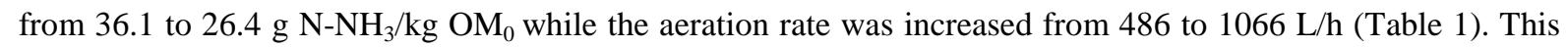
decrease could be due to a lower ammonification rate at $1066 \mathrm{~L} / \mathrm{h}$ than at $486 \mathrm{~L} / \mathrm{h}$ (Table 2), which may result from limitation of biodegradation because of a higher kinetic of drying at $1066 \mathrm{~L} / \mathrm{h}$.

Concerning nitrous oxide emissions, these were negligible during composting of household waste and food waste. They ranged between 2.2 and $4.5 \mathrm{~g} \mathrm{~N}-\mathrm{N}_{2} \mathrm{O} / \mathrm{kg} \mathrm{OM}_{0}$ for the green algae i.e. in the same range as ammonia emissions (Table 1).

Figure 2 here

Table 1 here

\subsection{Nitrogen balance}

Taking into account neither nitrite nor nitrate were found in initial waste and in composts, total nitrogen in initial waste and composts corresponded to Kjeldahl nitrogen. Initial contents in Kjeldahl nitrogen and its removal rates were given in Table 1 for each waste. Separated pig solids were characterized by low removal rates of initial content in nitrogen, between 5.8 and $8.3 \%$, whereas these were comprised between 36.7 and 43.1\%, 43.3 and 57.0\%, 48.4 and $66.2 \%$ and 39.6 and $56.3 \%$ for respectively household waste, food waste, pig slaughterhouse sludge and green algae (Table 1). During composting, nitrogen was either kept, either exported from material in leachates or emitted as ammonia, nitrous oxide and molecular nitrogen in exhaust gases. Losses of nitrogen as percent nitrogen removed from material were also given in Table 1. The nitrogen losses in leachates depended mostly on the amount of leachates i.e. on one hand on the substrates, their moisture content and their water holding capacity, and on the other, on aeration flow. However, the nitrogen losses in leachates also depend on nitrogen dynamic in the composting material i.e. on transformations and transfer of nitrogen. Table 1 shows that, in this study, these losses were all the higher as the aeration rate was low. Thus, these losses 
represented until $50 \%$ of nitrogen removed from pig slaughterhouse sludge at $105 \mathrm{~L} / \mathrm{h}$. Losses as ammonia represented from 0 to $83 \%$ of nitrogen removed. The cumulated losses of nitrogen i.e. in the leachates, in the condensates, as ammonia and as nitrous oxide, accounted for 1 to $91 \%$ of nitrogen removed from the material. Except for pig slaughterhouse sludge, more than $45 \%$ of nitrogen removed was always lacking in nitrogen balance (Table 1). For the household waste, this default was even superior to $97 \%$ (Table 1). N lacking in nitrogen balance was considered as molecular nitrogen emitted following nitrification and denitrification as usually assumed in literature. Figure 3 gives an illustration of the concentrations in N-NK in initial waste and of nitrogen kept in material, lost in leachates and emitted as $\mathrm{NH}_{3}, \mathrm{~N}_{2} \mathrm{O}$ and $\mathrm{N}_{2}$ in each experiment performed. In case of separated pig solids and pig slaughterhouse sludge, nitrous oxide was not measured and it was accounted as $\mathrm{N}_{2}$ emissions. Thus, nitrogen removed from material was emitted mainly as $\mathrm{N}_{2}$ for household waste and green algae whereas it was emitted mainly as $\mathrm{NH}_{3}$ for pig slaughterhouse sludge (Figure 3).

Figure 3 here

\subsection{Influence of ammonification on nitrogen removal and on ammonia emissions}

Taking into account that the total ammoniacal nitrogen was not quantified in the food waste and composted ones, food waste was excluded from part of the following discussion.

The ammonification rates were given in Table 2. As mentioned earlier, the removal of nitrogen from material results at first from the transformations and the transfer of total ammoniacal nitrogen (Figure 1). More, ammonification leads to the release of total ammoniacal nitrogen. Then, ammonification has a potential influence on removal rates of nitrogen from material. Figure 4 confirmed this influence. Indeed, the removal rate of Kjeldahl nitrogen was shown closely correlated to the removal rate of organic nitrogen through ammonification. Thus, the removal rates of Kjeldahl nitrogen and the ammonification rates were around $40 \%$ for household waste and between 50 and $70 \%$ for pig slaughterhouse sludge and green algae. Separated pig solids exhibited some negative ammonification rates. Thus, in the case of separated pig solids, the immobilization of total ammoniacal nitrogen as organic nitrogen in biomass and humic substances was superior to its release by ammonification. In contrast, for household waste, pig slaughterhouse sludge and green algae, immobilization was lower than ammonification. It was not possible to identify any direct influence of the aeration rate on the removal rate of Kjeldahl nitrogen (Table 1) neither on the ammonification rate (Table 2).

Table 2 here

Figure 4 here 
In literature, many authors suggested that ammonification was linked to the biodegradation of the organic matter. Liang et al. (2004) proposed a linear relationship between both as:

$$
\Delta \text { Norg } \approx \Delta T C \times\left[1 /\left(C_{b i o} / N_{b i o}\right)\right]
$$

with $\Delta$ Norg, the amount of organic nitrogen ammonified during composting, $\Delta \mathrm{TC}$, the amount of carbon removed during composting, and $\mathrm{C}_{\mathrm{bio}} / \mathrm{N}_{\mathrm{bio}}$, the ratio of carbon to nitrogen concentrations of the biodegraded fraction. $\Delta \mathrm{TC}$ was previously calculated in Part 1 . Both $\Delta$ Norg and $\Delta \mathrm{TC}$ are given in Table 2. Figure 5 gives an illustration of $\Delta$ Norg as function of $\Delta \mathrm{TC}$. Although the regression coefficients of the linear correlations are low for pig slaughterhouse sludge and separated pig solids, $\mathrm{C}_{\mathrm{bio}} / \mathrm{N}_{\text {bio }}$ ratios were calculated for each waste thanks to the measurement of the slopes corresponding to $\left[1 /\left(\mathrm{C}_{\mathrm{bio}} / \mathrm{N}_{\mathrm{bio}}\right)\right]$ (Table 2). Figure 5 illustrates well that the ammonification ability differs significantly from one waste to another. Thus, the green algae were the waste which biodegradation was responsible for the highest removal in organic nitrogen, i.e. the highest release in total ammoniacal nitrogen, per unit mass of carbon removed. However, although $\mathrm{C}_{\mathrm{bio}} / \mathrm{N}_{\text {bio }}$ was lower for green algae than for pig slaughterhouse sludge, 5 against 10 , since biodegradability of pig slaughterhouse sludge is much higher than the one of green algae, the composting of pig slaughterhouse sludge until stabilisation will release more total ammoniacal nitrogen than green algae. In contrast, taking into account that $\mathrm{C}_{\mathrm{bio}} / \mathrm{N}_{\text {bio }}$ ratio was superior for household waste than for green algae, 45 against 5, and that the biodegradability of household waste was superior to the one of green algae, composting of household waste was responsible for a lower release of total ammoniacal nitrogen than green algae. The negative value of $\mathrm{C}_{\mathrm{bio}} / \mathrm{N}_{\text {bio }}$ obtained for separated pig solids illustrated that for separated pig solids, immobilization of total ammoniacal nitrogen as organic nitrogen was higher than ammonification.

\section{Figure 5 here}

For a given waste, the proposed relationship shows that the total ammoniacal nitrogen released by ammonification is all the higher as $\mathrm{C}_{\mathrm{bio}} / \mathrm{N}_{\text {bio }}$ is low and as biodegradation rate is high, leading potentially to higher emissions of ammonia. Figure 6a confirmed that the ammonia emissions were all the lower as the ratio $\mathrm{C}_{\mathrm{bio}} / \mathrm{N}_{\text {bio }}$ was high. However, it was not possible to observe any reduction of ammonia emissions when the content in biodegradable carbon increased (Figure 6b). In contrast, the ammonia emissions were all the higher as $\mathrm{N}_{\text {bio }}$ contained in initial material was high (Figure 6c). Then, here, the decrease of ammonia emissions when $\mathrm{C}_{\text {bio }} / \mathrm{N}_{\text {bio }}$ increased was due to the decrease of $\mathrm{N}_{\text {bio }}$ rather than to the increase of $\mathrm{C}_{\text {bio. }}$. 


\subsection{Accumulation versus striping or nitrification of $\mathrm{NH}_{4}^{+} / \mathrm{NH}_{3}$}

The rates of accumulation, striping and nitrification were calculated for each experiment in order to identify the parameters ruling the transformations of the pool $\mathrm{P}$ defined as total ammoniacal nitrogen initially contained in waste plus total ammoniacal nitrogen released by ammonification. The accumulation rate, the striping rate and the nitrification rate were represented on Figure 7 as function of the aeration rate, the concentration of the pool $\mathrm{P}$ in the biofilm, the mean temperature of the material during composting and its content in biodegradable carbon. The concentration of $\mathrm{P}$ in the biofilm was estimated by dividing the amount of $\mathrm{P}$ by the mean amount of water in the material during composting:

$$
m \mathrm{H}_{2} \mathrm{O}_{\text {mean }} \approx\left[\mathrm{mH}_{2} \mathrm{O}_{0}+m \mathrm{H}_{2} \mathrm{O}_{\text {end }}\right] / 2 \text {. }
$$

The mean temperature, the maximum temperature and the mean content in water in the material during composting are given in Table 3.

At first, it can be noted that separated pig solids is characterised by a high ability to retain $\mathrm{NH}_{4}{ }^{+} / \mathrm{NH}_{3}($ Figure 7a), pig slaughterhouse by a high sensitivity to striping (Figure 7b) and household waste and green algae by a high ability to nitrification (Figure 7c).

Considering processes, it seemed that the accumulation rate decreased slightly when the aeration rate increased (Figure 7a). Except for household wastes, which were characterized by a high ability to nitrify, the accumulation rate decreased strongly when the pool concentration increased (Figure 7d). These results confirm the influence of ammonification rate on ammonia emissions and are in agreement with the basic knowledge on mass transfer between liquid and gaseous phases. It was not possible to find any evident influence of the mean temperature (Figure $7 \mathrm{~g}$ ) and of the initial content in biodegradable carbon (Figure $7 \mathrm{j}$ ) on the accumulation rate.

As result of the decrease of accumulation when the aeration rate and the pool concentration increased, Figures $7 \mathrm{~b}$ and $7 \mathrm{e}$ confirmed the increase of the striping rate when the aeration rate and the pool concentration increased. In opposition to assumptions of the literature, the mean and the maximum temperatures (Table 3, Figure $7 \mathrm{~h}$ ) were not evident parameters of ammonia emissions. Thus, the striping rate of separated pig solids was inferior to $10 \%$ whereas its mean temperature during composting was around $50^{\circ} \mathrm{C}$. It was not found any correlation between the striping rate and the initial content in biodegradable carbon (figure $7 \mathrm{k}$ ).

The nitrification rate seemed poorly influenced by the aeration rate (Figure 7c). It should be mentioned that, except for pig slaughterhouse sludge at $105 \mathrm{~L} / \mathrm{h}$, the oxygen supply was never limiting (Part 1), meaning that such limitation could not be invoked to explain the discards regards to nitrification rates. The low decrease of the nitrification rate of pig slaughterhouse sludge when the aeration rate was increased was a result of its low 
ability to retain total ammoniacal nitrogen and its high sensitivity to striping. Although it is not so evident, it seemed that the rate of nitrification decreased when the pool concentration increased (Figure $7 \mathrm{f}$ ), and that nitrification was maximum when temperature was around $35^{\circ} \mathrm{C}$ and decreased with lower or higher temperatures (Figure 7i). This result agreed with literature in which high concentrations in total ammoniacal nitrogen and high temperatures were assumed to slow down and even inhibit nitrification (Bishop and Godfrey, 1983; Eiland et al., 2001; Körner et al., 1999; Körner and Stegmann, 2003; Tiquia and Tam, 2000; Wong et al., 2001). The content in biodegradable carbon (Figure 71) was not found influent of nitrification process, neither the $\mathrm{pH}$ of the initial wastes, ranging between 6.6 and 8.7.

Back considering specific behaviour of each waste, the separated pig solids were characterised by a high ability to retain $\mathrm{NH}_{4}^{+} / \mathrm{NH}_{3}$ (Figure 7 a), which was supported by a medium concentration of $\mathrm{NH}_{4}^{+} / \mathrm{NH}_{3}$ in the biofilm (Figure 7d). Comparing to other wastes studied, separated pig solids were constituted of finer solid particles. Thus, assuming a high specific surface, this last may also explain this high retention capacity. As result of its high accumulation capacity, the striping rate of separated pig solids was low and poorly sensitive to the aeration rate (Figure $7 \mathrm{~b}$ ). Other parameters like $\mathrm{pH}$ and conductivity should be investigated in order to explain its behaviour and especially its low nitrification ability.

The pig slaughterhouse sludge were characterized by their rather high ability to striping (Figure 7b), which can be explained by their higher concentrations in $\mathrm{NH}_{4}{ }^{+} / \mathrm{NH}_{3}$ in comparison with the other waste (Figure 7e). These higher concentrations explained its low accumulation ability too (Figure $7 \mathrm{~d}$ ). At $105 \mathrm{~L} / \mathrm{h}$, the $\mathrm{pH}$ of pig slaughterhouse sludge ranged between 8.4 and 8.7. Although the $\mathrm{pH}$ at $105 \mathrm{~L} / \mathrm{h}$ was higher than at 486 and 1066 $\mathrm{L} / \mathrm{h}$, ammonia striping was lower. The increase of the striping rate with the aeration rate was interpreted as being responsible for the simultaneous decrease of its accumulation (Figure 7a) and nitrifying (Figure 7c) abilities. However, the nitrifying ability of pig slaughterhouse sludge reached $25 \%$ at the lowest aeration rate $(105 \mathrm{~L} / \mathrm{h})$ which could mean that pig slaughterhouse sludge was able to nitrify provided the residence time of $\mathrm{NH}_{4}{ }^{+} / \mathrm{NH}_{3}$ was sufficient. In other words, in the case of pig slaughterhouse sludge, the nitrification kinetic seemed lower than the striping one leading to low nitrification rates. However, further specific experiments are needed for explaining this behaviour regarding nitrification.

The household wastes were characterized by their high ability to nitrification (Figure 7c) which reduced their accumulation and striping abilities around zero. All the total ammoniacal nitrogen released by ammonification was nitrified. The higher ability to nitrification of household waste coincided with an initial concentration in $\mathrm{NH}_{4}{ }^{+} / \mathrm{NH}_{3}$ around zero (Table 1 in Part 1) which could mean that nitrification was already in progress in initial 
substrates and that a nitrifying biomass was already present within. The household waste are characterised by a high content in paper i.e. cellulose, which could favour the development of nitrifying microorganisms too.

Finally, the green algae were characterized by their rather high ability to nitrification (Figure 7c). This could be partly explained by the fact that these algae develop in seawaters with high concentrations in phosphorus and nitrogen. As for household waste, this ability coincided with low concentrations in $\mathrm{NH}_{4}^{+} / \mathrm{NH}_{3}$ in initial materials (Table 1 in Part 1 ). Although the striping rates of green algae were rather low, their increase with the aeration rate was also favoured by the rather high concentrations in $\mathrm{NH}_{4}{ }^{+} / \mathrm{NH}_{3}$ in the biofilm (Figure $7 \mathrm{e}$ ).

Figure 7 here

Taking into account the previous observations, the nitrification rate was represented as function of the initial concentration in total ammoniacal nitrogen in the waste. Figure 8 let think that the concentration in $\mathrm{NH}_{4}{ }^{+} / \mathrm{NH}_{3}$ in the initial waste was an indicator of the nitrification ability of the waste. Indeed, the higher was this concentration in the waste, the lower was the waste ability to nitrification. Thus, the low concentrations in $\mathrm{NH}_{4}^{+} / \mathrm{NH}_{3}$ in initial materials could mean that nitrifying microorganisms are already present within and that nitrification is already in progress. Moreover, high concentrations of $\mathrm{NH}_{4}{ }^{+} / \mathrm{NH}_{3}$ could mean that nitrifying microorganisms develop very slowly as demonstrated by Blouin et al. (1990). These results also suggest that nitrification ability is an intrinsic property of the waste and then that process conditions have a low influence on this ability. However, further experiments should be performed in order to characterise the nitrifying biomass in the waste. These should be completed by a chemical and biochemical characterisation in order to identify if $\mathrm{pH}$, conductivity or some biochemical fractions influenced the development of the nitrifying microorganisms.

Figure 8 here

\section{Conclusion}

Household waste, separated pig solids, food waste, pig slaughterhouse sludge and green algae were compared regarding processes ruling nitrogen dynamic in composting. The removal rate of total nitrogen was demonstrated being closely correlated to the ammonification rate. The ratio of biodegradable carbon to ammonifiable organic nitrogen, $\mathrm{C}_{\mathrm{bio}} / \mathrm{N}_{\mathrm{bio}}$, was calculated for each waste. The green algae were responsible for the highest release of total ammoniacal nitrogen per unit mass carbon biodegraded whereas household waste led to the lowest one. In contrast, the biodegradation of separated pig solids led to the immobilization of $\mathrm{NH}_{4}^{+} / \mathrm{NH}_{3}$. The waste content in ammonifiable organic nitrogen, $\mathrm{N}_{\text {bio }}$, and the aeration rate applied were found the most predominant parameters of ammonia emissions. Nitrogen balances showed that losses in leachates and as ammonia and nitrous oxide accounted for 1 to $91 \%$ of nitrogen removed from material. Except for pig 
1 slaughterhouse sludge, the gap between nitrogen removed from material and losses in leachates and as ammonia

2 and nitrous oxide exceeded $45 \%$ meaning a large part of nitrogen removed was nitrified, then, transferred to 3 atmosphere as molecular nitrogen. Neither aeration rate nor biodegradable carbon content were found influent of 4 nitrification rate. In contrast, the high nitrification rates of household waste and of green algae coincided with 5 the lowest concentration in total ammoniacal nitrogen in initial waste. Then, nitrification rate was found closely 6 correlated to this concentration. This could mean that, in case of low concentration in total ammoniacal nitrogen 7 in initial waste, nitrification was already in progress and that in case of high concentrations, nitrifying microorganisms develop slowly. Further experiments have to be performed in order to quantify nitrifying

9 microorganisms and to investigate if their development was correlated with chemical or biochemical 10 characteristics of the wastes. 
This research was funded by ADEME, the French Agency for Environment and Energy Management, the 3 Regional Council and the Regional Direction of the Ministry of Agriculture and forestry (DRAF) of Brittany.

4 The data on green algae were obtained through a study in collaboration with Jean-François Sassi from CEVA 5 (Centre d'Etude et de Valorisation des Algues). 


\section{References}

Beck-Friis, B., Smars, S., Jonsson, H. and Kirchmann, H., 2001. Gaseous emissions of carbon dioxide, ammonia and nitrous oxide from organic household waste in a compost reactor under different temperature regimes. Journal of Agricultural Engineering Research. 78: 423-430.

Bhoyar, R., Olaniya, M. and Bhide, A., 1979. Effect of temperature on mineralization of nitrogen during aerobic composting. Indian Journal of Environmental health 21: 23-24.

Bishop, P. L. and Godfrey, C., 1983. Nitrogen transformations during sludge composting. BioCycle July/August: 34-39.

Blouin, M., Bisaillon, J.-G., Beaudet, R. and Ishaque, M., 1990. Nitrification of swine waste. Canadian Journal of Microbiology(36): 273-278.

Cronje, A. L., Barker, A. J., Guy, S., Turner, C. and Williams, A. G., 2002. Ammonia emissions and pathogen inactivation during composting. In: Proceedings of the 2002 International Scientific Symposium on Composting and Compost Utilization, 6-8 may, Colombus, USA, Published on CD-ROM.

de Guardia, A., Petiot, C., Rogeau, D. and Druilhe, C., 2008. Influence of aeration rate on nitrogen dynamics during composting. Waste Management 28(3): 575-587.

Eiland, F., Leth, M., Klamer, M., Lind, A. M., Jensen, H. E. K. and Iversen, J. J. L., 2001. C and N turnover and lignocellulose degradation during composting of Miscanthus straw and liquid pig manure. Compost Science \& Utilization 9(3): 186-196.

Ekinci, K., Keener, H. M. and Elwell, D. L., 2000. Composting short paper fiber with broiler litter and additives part I : Effects of initial $\mathrm{pH}$ and carbon/nitrogen ratio on ammonia emission. Compost Science \& Utilization 8(2): 160172.

Kirchmann, H. and Witter, E., 1989. Ammonia volatilizationduring aerobic and anaerobic manure decomposition. Plant and Soil 115(1): 35-41.

Komilis, D. P. and Ham, R. K., 2006. Carbon dioxide and ammonia emissions during composting of mixed paper, yard waste and food waste. Waste Management 26(1): 62-70.

Körner, I., Brilsky, H., Jensen, U., Ritzkowski, M. and Stegmann, R., 1997. Possibilities for the regulation of the composting process to optimize the nutrient composition of compost. In: Proceedings of the International Conference of ORBIT Association: Organic Recovery \& Biological Treatment in the next Millenium, 3-5 September, Harrogate, United Kingdom, Zeebra Publishing, Manchester and Ritchie.

Körner, I., Schlegelmilch, M. and Stegmann, R., 1999. Regulation of nitrogen contents of composts during composting - first experimental results. In: Proceedings of the international Conference of ORBIT Association on Research in and Implementation of Process Technology Treatment, 2-4 September, Weimar, Germany, Rhombos-Verlag, Berlin, ISBN 3-930894-20-3.

Körner, I. and Stegmann, R., 2003. Comparison of the N-contents of substrates during composting in facilities working with different technologies. In: Proceedings of the Fourth International Conference of ORBIT Association on Biological Processing of Organics: Advances for a sustainable Society, 30th April-2 may, Perth, Australia.

Lemus, G. R. and Lau, A. K., 2002. Effect of carbon availability on greenhouse gases emissions and nitrogen conservation during high rate composting. In: Proceedings of the International Scientific Symposium on Composting and Compost Utilization, 6-8 may, Colombus, USA, Published on CD-ROM.

Liang, Y., Leonard, J. J., Feddes, J. and McGill, W., 2004. a simulation model of ammonia volatilization in composting. Transactions of the ASAE 47(5): 1667-1680.

Liang, Y., Leonard, J. J., Feddes, J. J. R. and McGill, W. B., 2006. Influence of carbon and buffer amendment on ammonia volatilization in composting. Bioresource Technology 97(5): 748-761.

Mallard, P., Rogeau, D., Gabrielle, B., Vignoles, M., Sablayrolles, C., Le Corff, V., Carrere, M., Renou, S., Vial, E., Muller, O., Pierre, N. and Coppin, Y., 2006. Environmental impacts of biological treatments of waste - state of the art (Impacts environnementaux de la gestion biologique des déchets - Etat des connaissance). Ademe Editions: pp 3150 .

Martins, O. and Dewes, T., 1992. Loss of nitrogenous compounds during composting of animal wastes. Bioresource Technology 42(2): 103-111.

Okereke, G. U. and Meints, V. W., 1985. Immediate immobilization of labeled ammonium sulfate and urea nitrogen in soils. Soil Science 140: 105-109.

Pagans, E., Barrena, R., Font, X. and Sanchez, A., 2006. Ammonia emissions from the composting of different organic wastes. Dependency on process temperature. Chemosphere 62(9): 1534-1542.

Paillat, J. M., Robin, P., Hassouna, M. and Leterme, P., 2005. Predicting ammonia and carbon dioxide emissions from carbon and nitrogen biodegradability during animal waste composting. Atmospheric Environment 39(36): 68336842.

Paré, T., Dinel, H., Schnitzer, M. and Dumontet, S., 1998. Transformations of carbon and nitrogen during composting of animal manure and shredded paper. Biology and Fertility of Soils 26(3): 173-178.

Subair, S., 1995. Reducing ammonia volatilization from liquid hog manure by using organic amendments, M. Sc. Thesis, McGill University, Montreal, Canada.

Tiquia, S. M. and Tam, N. F. Y., 2000. Fate of nitrogen during composting of chicken litter. Environmental Pollution 110(3): 535-541.

Witter, E., 1986. The fate of nitrogen during high temperature composting of sewage sludge-straw mixtures, Ph.D. thesis, University of London.

Witter, E. and Lopez-Real, J., 1987. The potential of sewage sludge and composting in a nitrogen recycling strategy for agriculture. Biological Agriculture and Horticulture(5): 123. 
1 Wong, J. W., Mak, K. F., Chan, N. W., Lam, A., Fang, M., Zhou, L. X., Wu, Q. T. and Liao, X. D., 2001. Co-composting of 2 soybean residues and leaves in Hong Kong. Bioresource Technology 76(2): 99-106.

3 Zhu, N., 2007. Effect of low initial $\mathrm{C} / \mathrm{N}$ ratio on aerobic composting of swine manure with rice straw. Bioresource 4 Technology 98(1): 9-13. 
Table 1:

Ammonia and nitrous oxide emissions and nitrogen balance

\begin{tabular}{|c|c|c|c|c|c|c|c|c|c|c|}
\hline & \multirow{2}{*}{$\begin{array}{c}\begin{array}{c}\text { Aeration } \\
\text { rate }\end{array} \\
\text { L/h }\end{array}$} & \multicolumn{2}{|c|}{$\begin{array}{c}\mathrm{N}_{2} \mathrm{O} \text { and } \mathrm{NH}_{3} \\
\text { emissions }\end{array}$} & \multirow{2}{*}{$\begin{array}{c}\begin{array}{c}\text { Initial } \\
\text { content } \\
\text { in N- } \\
\text { NK }\end{array} \\
\begin{array}{c}\text { g N/kg } \\
\mathrm{OM}_{0}\end{array}\end{array}$} & \multirow{2}{*}{$\begin{array}{c}\text { Removal } \\
\text { rate of } \\
\text { N-NK } \\
\%\end{array}$} & \multicolumn{3}{|c|}{$\begin{array}{c}\text { Losses in nitrogen as } \\
\text { percent total nitrogen } \\
\text { removed from material }(\%)\end{array}$} & \multicolumn{2}{|c|}{$\begin{array}{l}\text { Closure in } \\
\text { nitrogen }^{4}\end{array}$} \\
\hline & & $\begin{array}{c}\mathrm{g} \mathrm{N}- \\
\mathrm{NH}_{3} / \mathbf{k g} \\
\mathrm{OM}_{0}^{1}\end{array}$ & $\begin{array}{c}\text { g N- } \\
\mathrm{N}_{2} \mathrm{O} / \mathrm{kg} \\
\mathrm{OM}_{0}\end{array}$ & & & Leach. $^{2}$ & Cond. ${ }^{3}$ & $\mathbf{N}_{2} \mathbf{O}$ & $\mathbf{N H}_{3}$ & $\%$ \\
\hline \multirow[t]{3}{*}{ HW } & 117 & 0.0 & 0.0 & 22.4 & 36.7 & 2.3 & 0.0 & 0.1 & 0.0 & -97.6 \\
\hline & 394 & 0.1 & 0.0 & 22.4 & 43.1 & 0.2 & 1.3 & 0.0 & 0.0 & -98.5 \\
\hline & 746 & 0.1 & 0.0 & 22.4 & 41.3 & 0.2 & 0.8 & 0.0 & 0.0 & -99.0 \\
\hline \multirow[t]{3}{*}{ SPS } & 166 & 1.1 & $\mathrm{~nm}^{5}$ & 43.1 & 5.8 & 0.0 & 35.2 & $\mathrm{~nm}$ & 10.9 & -53.9 \\
\hline & 226 & 1.0 & $\mathrm{~nm}$ & 43.1 & 5.9 & 0.0 & 27.0 & $\mathrm{~nm}$ & 13.0 & -60.1 \\
\hline & 443 & 1.7 & $\mathrm{~nm}$ & 43.1 & 8.3 & 0.0 & 25.0 & $\mathrm{~nm}$ & 23.4 & -51.6 \\
\hline \multirow[t]{3}{*}{ FW } & 138 & 5.5 & 0.1 & 43.4 & 57.0 & 13.1 & 12.9 & 0.5 & 9.4 & -64.1 \\
\hline & 372 & 8.1 & 0.0 & 43.4 & 43.3 & 11.6 & 12.5 & 0.0 & 30.4 & -45.4 \\
\hline & 773 & 10.8 & 0.0 & 43.4 & 50.9 & 4.4 & 9.6 & 0.0 & 39.2 & -46.8 \\
\hline \multirow[t]{3}{*}{ PSS } & 105 & 4.8 & $\mathrm{~nm}$ & 61.1 & 48.4 & 48.4 & 0.0 & $\mathrm{~nm}$ & 16.2 & -35.4 \\
\hline & 486 & 36.1 & $\mathrm{~nm}$ & 73.8 & 66.2 & 10.5 & 17.6 & $\mathrm{~nm}$ & 56.3 & -15.7 \\
\hline & 1066 & 26.5 & $\mathrm{~nm}$ & 55.0 & 57.5 & 7.1 & 0.5 & $\mathrm{~nm}$ & 83.3 & -9.2 \\
\hline \multirow[t]{6}{*}{ GA } & 156 & 2.9 & 2.2 & 65.9 & 42.6 & 0.0 & 0.0 & 8.0 & 10.5 & -81.5 \\
\hline & 391 & 6.6 & 4.5 & 65.9 & 39.6 & 0.0 & 0.0 & 17.3 & 25.3 & -57.5 \\
\hline & 721 & 9.3 & 3.6 & 65.9 & 56.3 & 0.0 & 0.0 & 9.6 & 25.0 & -65.4 \\
\hline & Mean & & & & & 6.5 & 9.5 & 3.9 & 22.8 & -58.8 \\
\hline & Max. & 36.1 & 4.5 & & & 48.4 & 35.2 & 17.3 & 83.3 & -9.2 \\
\hline & Min. & 0 & 0.0 & & & 0.0 & 0.0 & 0.0 & 0.0 & -99.0 \\
\hline
\end{tabular}

${ }^{1} \mathrm{NH}_{3}$ in gases plus condensates

${ }^{2}$ Leachates

${ }^{3}$ Condensates

${ }^{4}$ Closure in nitrogen: [(Losses in nitrogen in leachates + condensates and as $\mathrm{N}_{2} \mathrm{O}$ and $\left.\mathrm{NH}_{3}\right)-($ Nitrogen removed from material) ${ }^{*} 100 /($ Nitrogen removed from material)

${ }^{5} \mathrm{~nm}$ : not measured 
Table 2

Ammonification rate and Cbio/Nbio ratio of the biodegradable fraction

\begin{tabular}{|c|c|c|c|c|c|}
\hline & Aeration rate & Ammonification rate & $\Delta \mathbf{T C}$ & $\Delta$ Norg. & Cbio/Nbio \\
\hline & $L / h$ & $\%$ & g C/kg OM${ }_{0}$ & g N/kg OM & \\
\hline \multirow[t]{3}{*}{ HW } & 117 & 36.7 & 415.4 & 8.2 & \\
\hline & 394 & 43.1 & 427.4 & 9.7 & \\
\hline & 746 & 41.3 & 380.6 & 9.3 & 45 \\
\hline Mean & & & 407.8 & 9.1 & \\
\hline $\mathrm{CV}(\%)$ & & & 6.0 & 8.3 & \\
\hline \multirow[t]{3}{*}{ SPS } & 166 & -4.8 & 196.2 & -1.4 & \\
\hline & 226 & -7.5 & 210.6 & -2.1 & \\
\hline & 443 & -0.6 & 208.7 & -0.2 & -166 \\
\hline Mean & & & 205.2 & -1.7 & \\
\hline $\mathrm{CV}(\%)$ & & & 3.8 & -31.2 & \\
\hline \multirow[t]{3}{*}{ PSS } & 105 & 63.5 & 330.3 & 33.5 & \\
\hline & 486 & 71.4 & 287.7 & 44.8 & \\
\hline & 1066 & 52.0 & 328.3 & 21.0 & 10 \\
\hline Mean & & & 315.4 & 33.1 & \\
\hline $\mathrm{CV}(\%)$ & & & 7.6 & 36.0 & \\
\hline \multirow[t]{3}{*}{ GA } & 156 & 55.9 & 208.2 & 35.9 & \\
\hline & 391 & 50.2 & 197 & 32.2 & \\
\hline & 721 & 62.1 & 178.2 & 39.9 & 5 \\
\hline Mean & & & 194.5 & 36.0 & \\
\hline $\mathrm{CV}(\%)$ & & & 7.8 & 10.7 & \\
\hline
\end{tabular}


Table 3

Mean temperature, maximum temperature and mean content in water in material during composting

\begin{tabular}{ccccc}
\hline & Aeration rate & T mean & T max & $\begin{array}{c}\text { Mean content in } \\
\text { water }\end{array}$ \\
\cline { 2 - 5 } & L/h & ${ }^{\circ} \mathbf{C}$ & ${ }^{\circ} \mathbf{C}$ & ${\mathbf{~ k g ~ H} \mathbf{~} \mathbf{O} \mathbf{m}^{\mathbf{3}} \text { reactor }}^{\text {HW }}$ \\
\cline { 2 - 4 } & 117 & 38.5 & 55.2 & 198.5 \\
& 394 & 34.8 & 57.2 & 186.7 \\
& 746 & 34.4 & 57.1 & 169.8 \\
\hline SPS & 166 & 51.5 & 66.5 & 275.0 \\
& 226 & 47.6 & 65.5 & 285.0 \\
& 443 & 47.1 & 64.2 & 279.8 \\
\hline FW & 138 & 35.4 & 48.3 & 124.3 \\
& 372 & 32.6 & 47.3 & 118.8 \\
& 773 & 32.3 & 48.0 & 117.8 \\
\hline GA & 105 & 45.6 & 53.4 & 367.6 \\
& 486 & 45.9 & 68.4 & 354.3 \\
& 1066 & 43.4 & 66.7 & 317.7 \\
\hline
\end{tabular}




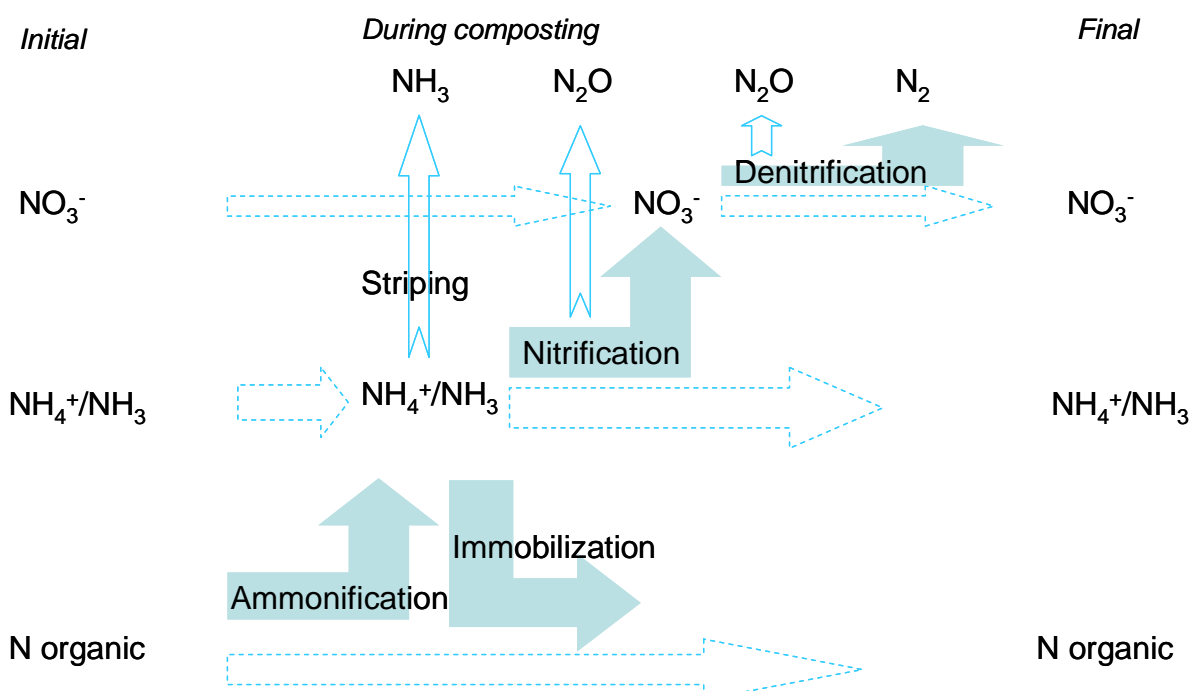

Accumulation in material and transfer to leachates Biological transformation

Transfer to atmosphere

Figure 1: Nitrogen transformations and transfers during composting. 

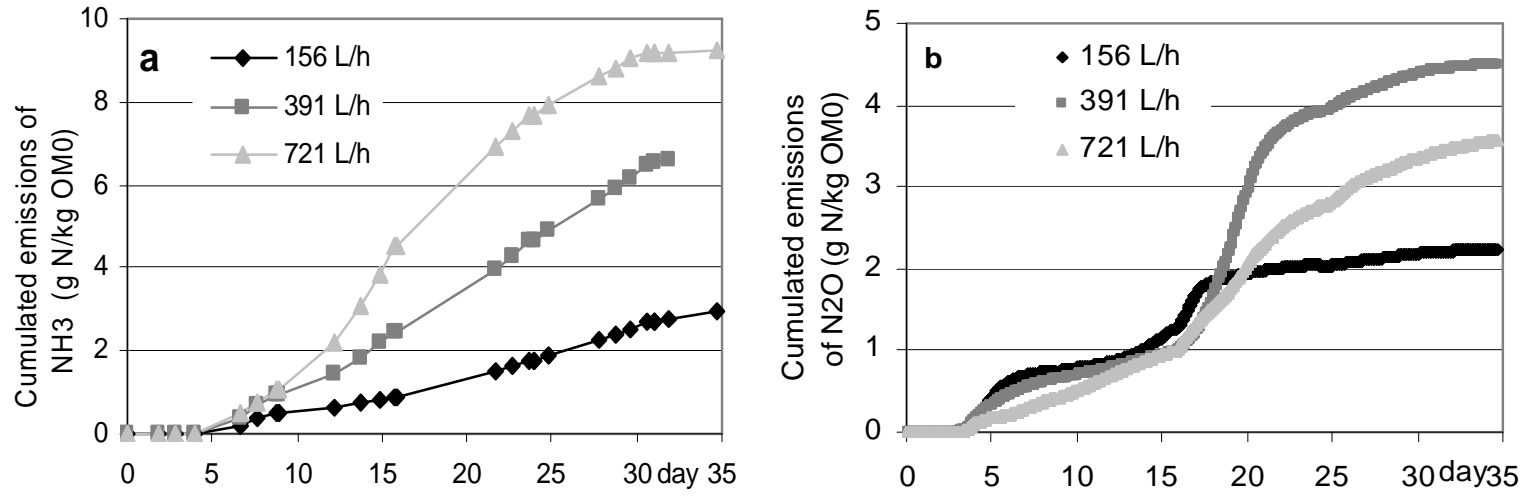

Figure 2: Cumulated emissions of ammonia and nitrous oxide during composting of green algae. 


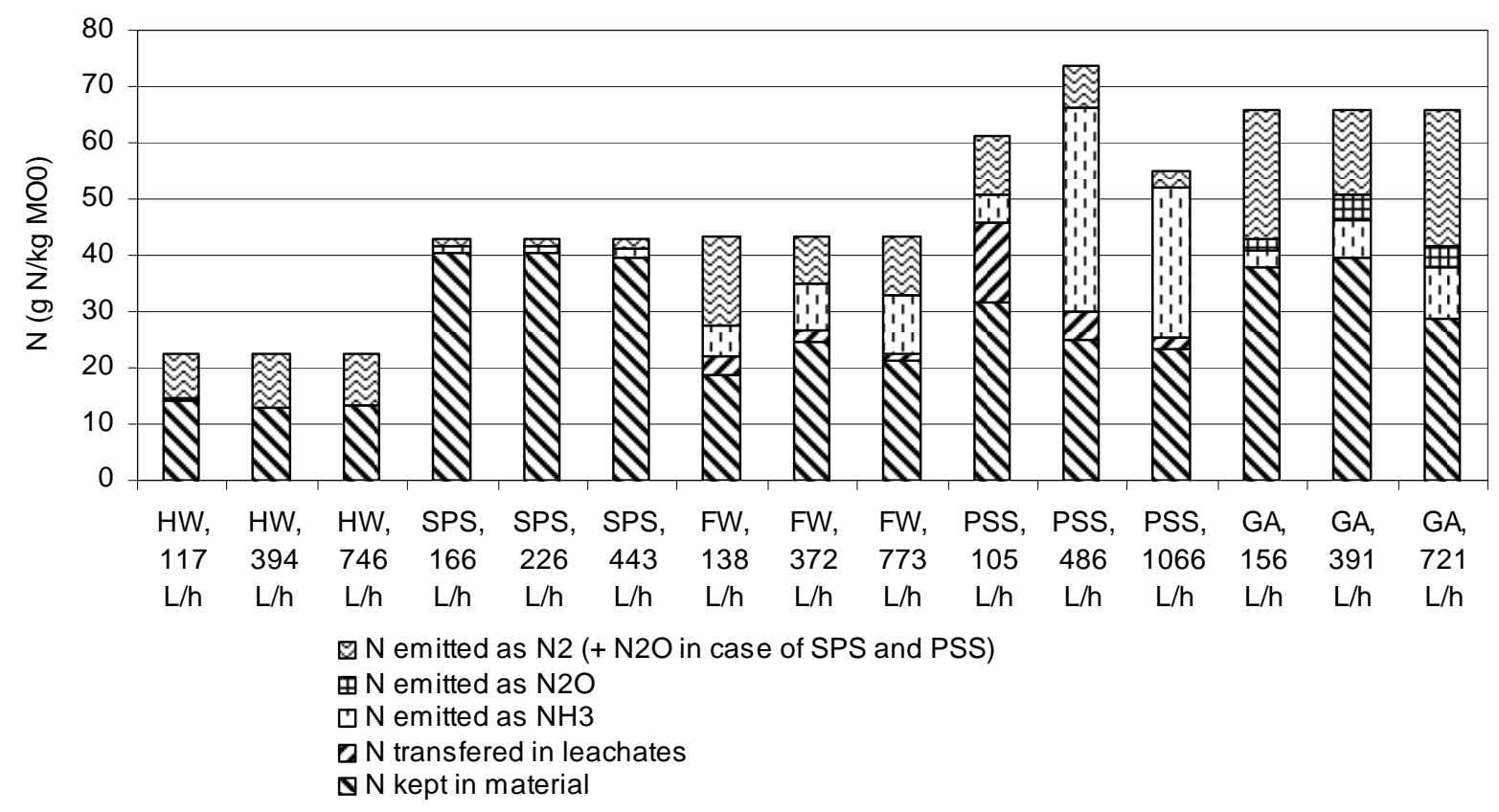

Figure 3: Accumulation and transfers of nitrogen as function of the aeration rate. 


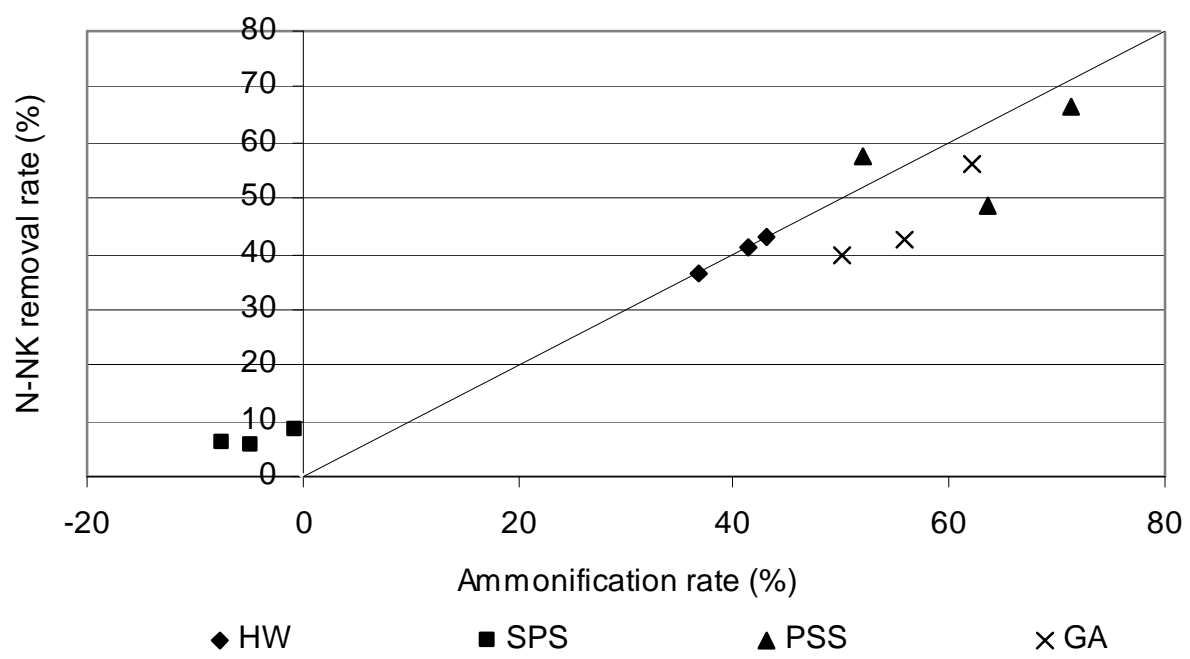

Figure 4: N-NK removal rate as function of ammonification rate. 


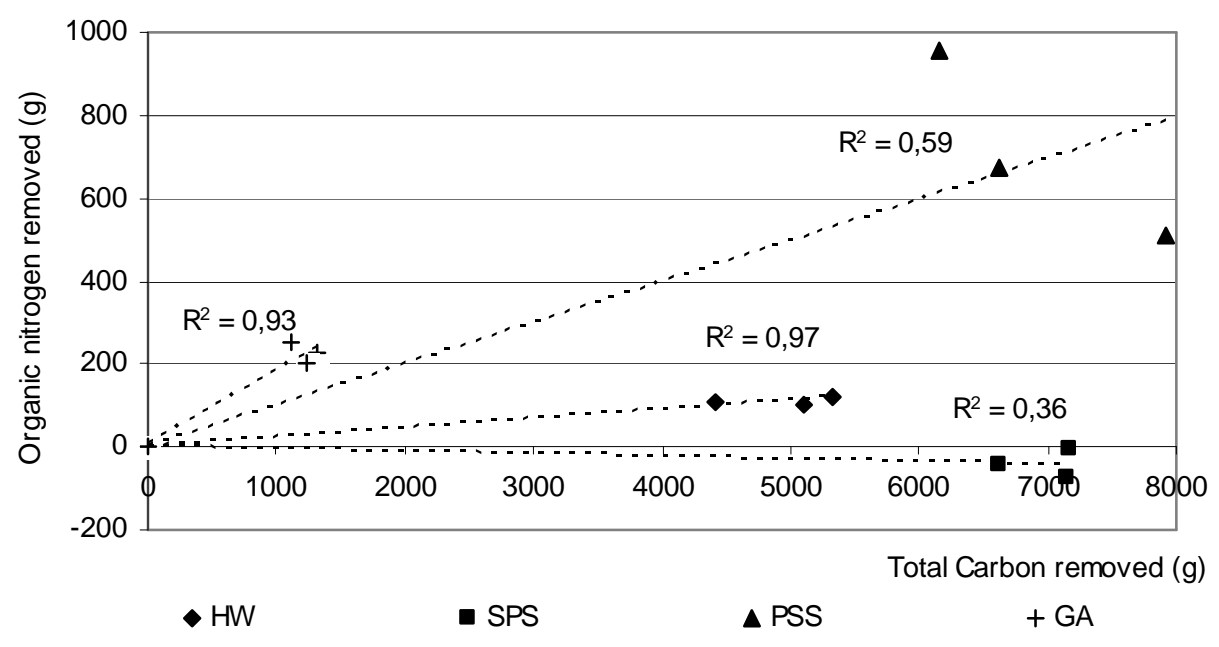

Figure 5: Organic nitrogen removal as function of carbon removal. 

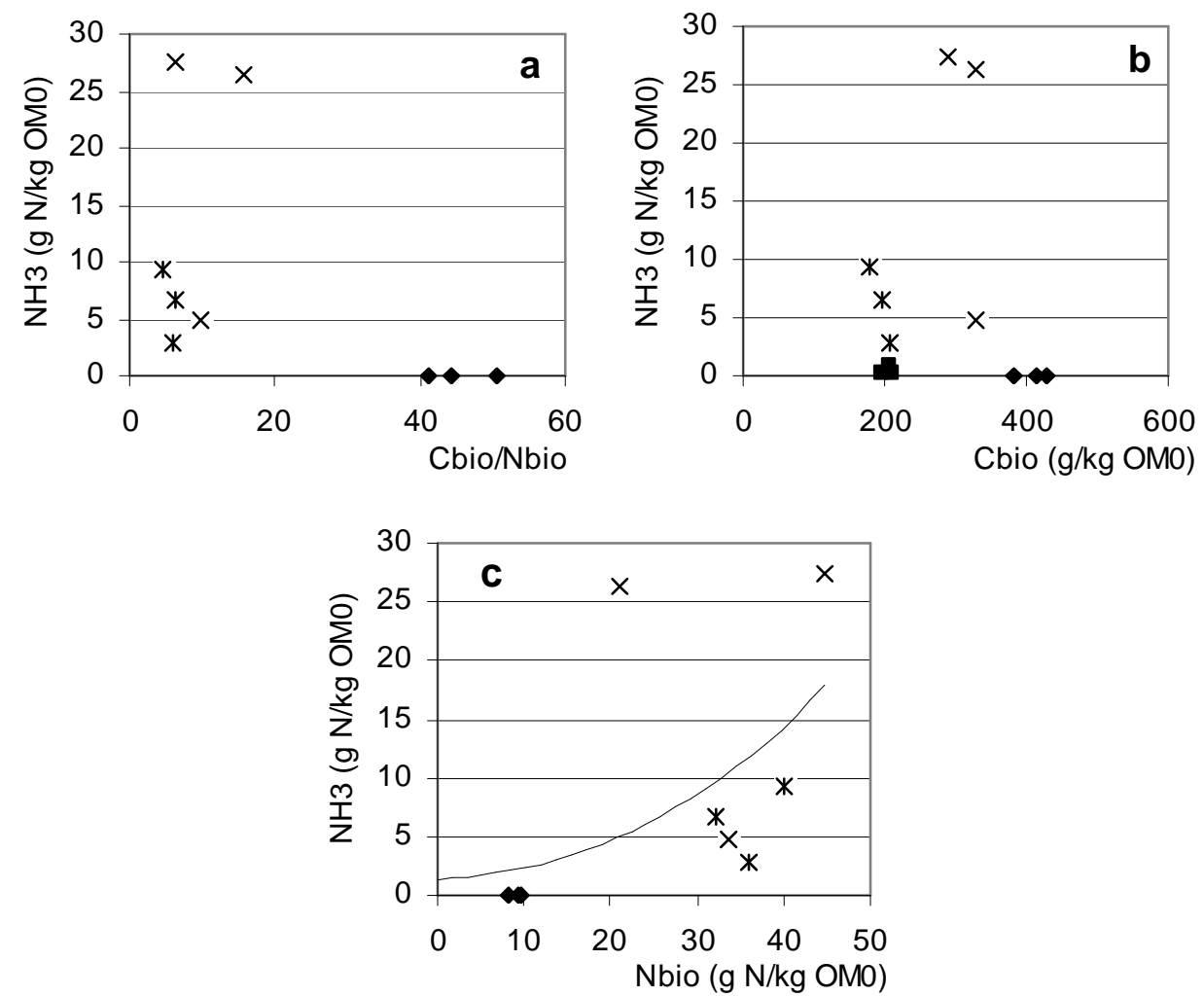

Figure 6: Influence of the contents in biodegradable carbon $\left(\mathrm{C}_{\text {bio }}\right)$, ammonifiable nitrogen $\left(\mathrm{N}_{\text {bio }}\right)$ and ratio $\mathrm{C}_{\text {bio }} / \mathrm{N}_{\text {bio }}$ on ammonia emissions. 

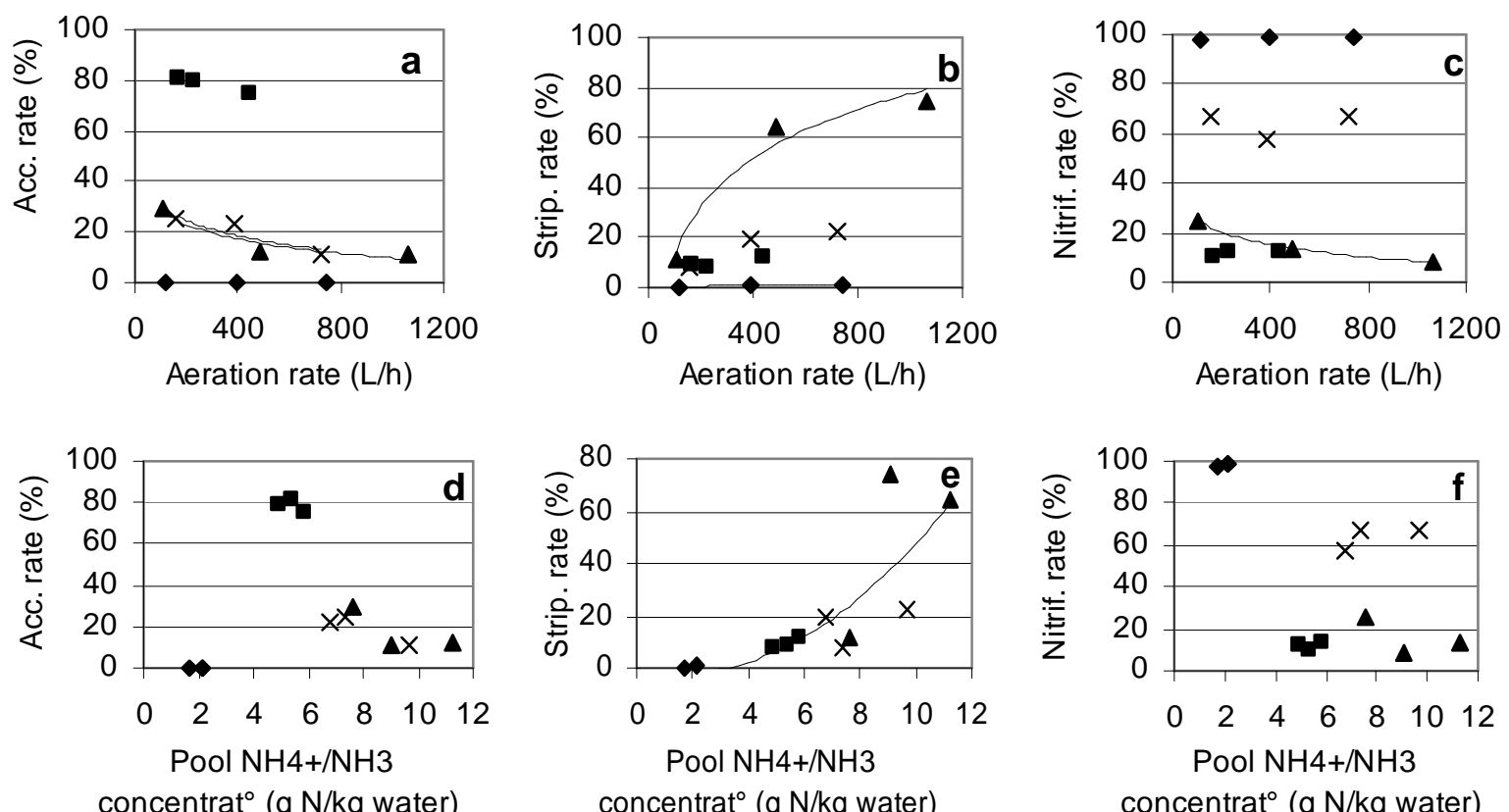

concentrat $^{\circ}$ ( $\mathrm{g} \mathrm{N} / \mathrm{kg}$ water)
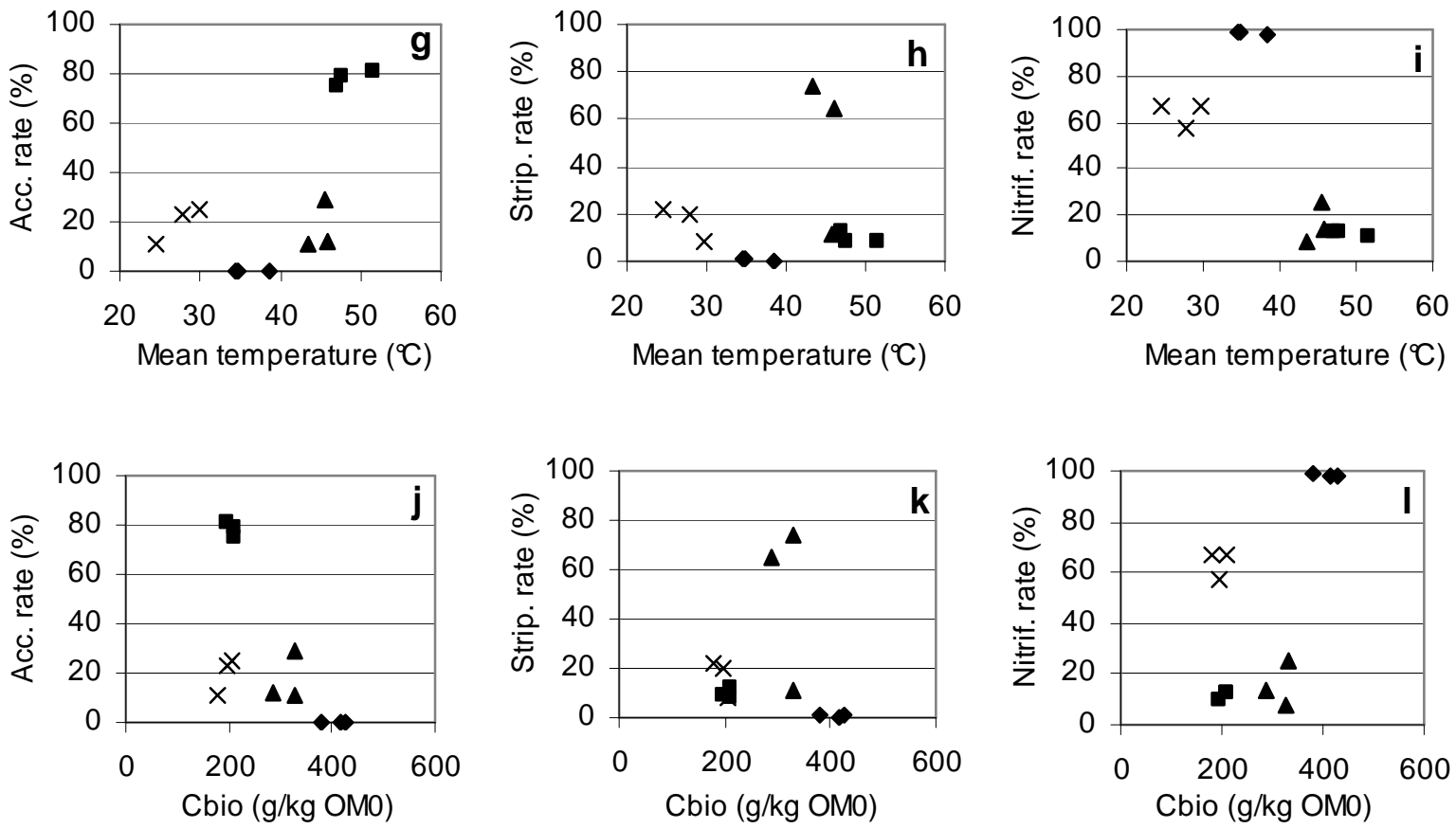

$\bullet \mathrm{HW}$

$\times G A$

Figure 7: Accumulation. striping and nitrification rates as function of aeration rate. $\mathrm{NH}_{4}{ }^{+} / \mathrm{NH}_{3}$ concentration. mean temperature and biodegradable carbon content. 


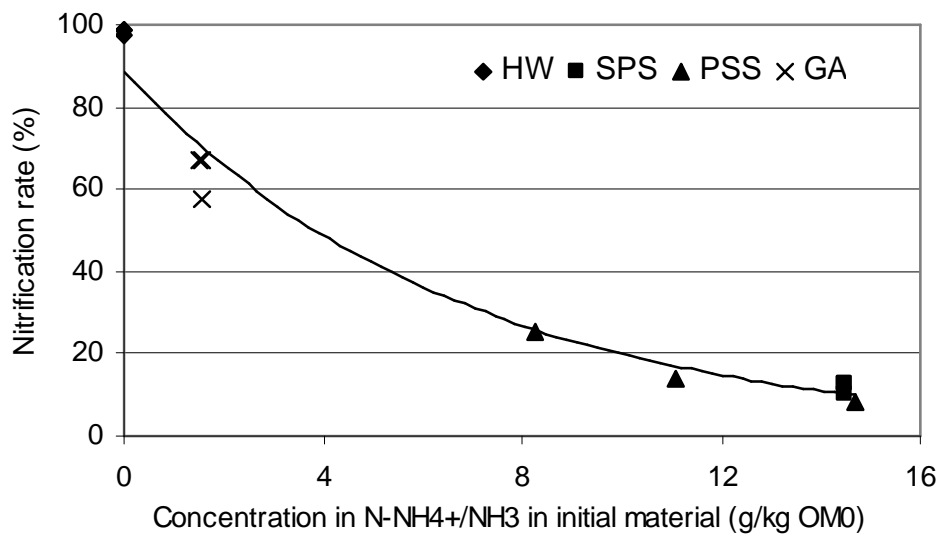

Figure 8: Nitrification rate as function of the concentration in $\mathrm{NH}_{4}{ }^{+} / \mathrm{NH}_{3}$ in the initial waste 